\section{TERRORISM IN THE NAME OF ISLAM: BANGLADESH PERSPECTIVE}

\section{Ayesha Siddika*}

\begin{abstract}
This research aims at exploring various factors of terrorism in the name of Islam in Bangladesh with a special preference to understand the causal relation between religion and terrorism. Bangladesh has been suffering from the crisis of religious militancy for the last couple of decades. Terrorist activities such as bombing, murder, burning houses, destructing temples and house of people belonging to other religions induced fear among the people of Bangladesh. Terrorists have been using the name of Islam as a safeguard of their heinous activities. This study argues that there is no connection between terrorism and Islam. This research finds that the lack of knowledge of the religion of Islam as well as other religions, unemployment, social media, global rise of militancy in the name of Islam and different psychological issues work behind terrorism in the name of Islam in Bangladesh. In the face of a global rise of religious militancy or militancy in the name of Islam, it requires a comprehensive study on terrorism in the name of Islam from the perspectives of Bangladesh.
\end{abstract}

* Lecturer, Department of World Religions and Culture, University of Dhaka, Email: ayesha.wrc@du.ac.bd
Key words: militancy, education, unemployment, terrorism, social media

\section{Introduction}

Terrorism is a global problem. Most of the terrorist acts are occurred in the name of religion and the terrorists try to justify their activities through religion. Islam, for instance, is widely used as safeguard for the terrorist organizations around the world (Hardy, 2018). Religion and terrorism are often castigated as synonyms while all the religions of the world teach peace. As a result, anti-religious mentality and abhorrence for religions are increasing day by day. The most victimized religion is Islam due to the repeated terror acts by the misguided so-called religious militant organizations such as Islamic States, Jamatul Mujahedin of Bangladesh, Al Qaida and many others. Islam is the scapegoat that is often wrongly identified as a religion of terrorism (Barakat, 2018). Islamophobia is now on high not only in the United States, but also in Europe, Australia and Latin America. The Muslims are humiliated as terrorists. This study is an initiative to find the main motive of terrorism and how the terrorists benefit by using the name of religion (Islam). After the attack of the 9/11 in the United States of America, the world has witnessed an unprecedented rise of religion-based extremism or militancy throughout the world and Bangladesh is no exception. In the face of deadly consequences of terrorist threats posed by the extremists, the world leaders have been trying to cut off the power of the militants from Europe to Asia, though they failed significantly. Terrorism in the name of Islam in Bangladesh started in 1990s when Harkatul Jihad (HUJI) tried to kill the then Prime Minister Sheikh Hasina and bombed at the Ramna 
Batamul on the Pohela Boishakh celebration gathering (Riaz, 2013). Later on, there emerged different militant groups with different visions but extreme in nature such as Ansarullah Bangla Team (ABT), Hijbut Tahrir (HT), Jamatul Mujahedin of Bangladesh (JMB) and Neo-JMB. It has been seen that the government has been trying to view these militant groups as homegrown terrorist groups. But the fact is that all these organizations have been keeping close ties with international terrorists' networks like Islamic States (IS) and Al-Quida (Though these organizations work in South Asia through AQIS). Neo-JMB has been alleged to be a sister concern of IS, whereas Ansarullah Banga Team keeps a close tie with AQIS (Ibid, 2016). It is estimated that between 2005 to 2016, terrorists have killed more than three hundred people in different areas of Bangladesh including writers, priests, civilians, foreigners and so on (Rahman, 2017). After the incident of Ramu Violence back in 2012 when the extremists destroyed some Buddhist pagodas in Bangladesh, the number of attacks on the minorities rose significantly. In this study, the probable causes of terrorism in Bangladesh in the name of Islam has been explored and shown that such terrorism has no connection with Islam.

\section{Methodology}

By nature, this research explores a social fact which requires qualitative approaches to be followed in this study. Qualitative approaches are used to explain a social crisis from in-depth perspectives (Islam and Faruque, 2017). This study has been conducted mainly based on fieldwork at Dhaka and secondary sources such as books, journals and newspapers. Besides an extensive literature review, a field work was carried out at the
University of Dhaka from August 2018 to December 2018 where five academics and researchers were interviewed on religious extremism. Purposive sampling Technique (PST) was used to select the respondents and a semi-structured interview was conducted by following Key Informant Technique (KIT). In this study, the names of the respondents have been used anonymously for avoiding any ethical concerns. Sample size was only five because after interviewing five respondents, no new data came on the concerned field. In addition, raw data has been destroyed for the sole purpose of this study. The study area was kept restricted within Dhaka for the availability of the respondents. Qualitative data has been analyzed manually, not using any software tool.

\section{Literature Review}

Like the Western countries, it is evident that the most of the extremists in Bangladesh are young (Bakker, 2006; Mostofa, 2019; Riaz and Parvez, 2018). There are number of reasons that work behind youth engagement in militancy. Hardy (2018) identifies that militancy has its roots in many socio-economic causes along with psychological issues. In the present days, the engagement of women in militancy is also visible in Bangladesh like other countries, though the percentage of women in militancy is very low. It is widely established in academic literature that the terrorists suffer from identity crisis. They believe that identity of the Muslim is in danger and this danger triggers a potential radical to get involved in violent activities. A failed integration in the pluralist society can also be a factor behind radicalization (Mazarr 2004) argued that various push and pull factors work behind radicalization. A negative social environment can trigger a potential radical to be 
violent. When a person is unemployed, this opportunity can be taken by the perpetrators. In addition, someone might join radical groups to gain glory which is explained by Farrall (2015) and Scott (2015). They argued that one of the key factors of terrorism campaign is to be glorified especially in the hereafter. Omar Taspanir (2009) argued that among all the social elements to turn make one a radical, relative deprivation is the key reason of terrorism. A relatively deprived person seeks his or her earnest motivation in terrorism in the name of religion. Hardy (2018) says that there is no relation between religion and terrorism. Religion is used as a tool by the terrorist groups. So, the conceptual debate of religion and terrorism is void and invalid. But the importance of ideology which can be driven by religion, society, country, political affiliation is important. Russell (2016) and Hoffman (2016) argued that extremists are motivated and guided by a set of ideological positions that drive them to be terrorist. Misinterpretation of sacred text is a major cause of terrorism in the name of religion, says Hafez and Mullins (2015). Identity crisis as a Muslim is also a reason for terrorism which is argued by Raffie (2013). Besides those, Islam (2019) has analyzed deradicalization process of different Muslim countries. Islam and Huda (2016) have analyzed intrinsic relationship between religion and politics in Bangladesh whereas Islam and Siddika (2020) have discussed a few causes of terrorism.

The above stated literatures certainly deserve merit and these literatures attempted to draw the debate whether there is connection between Islam and terrorism. But these studies were mainly based on western perspectives and lack primary data in many cases. In addition, a few literature on militancy in
Bangladesh has been written by Riaz (2008, 2016, 2018), Riaz and Parvez (2018), Parvez (2019), Mostofa (2019), Barkat (2018), Rahman (2017), Khan (2017), Chowdhury (2016) and Islam (2011) but lacks comprehensive analysis of the causes as to why people become militants in the name of Islam. Riaz (2013) argued that the politics of expediency is a viable environment for terrorism in Bangladesh. Political instabilities and political confrontations are important factors of terrorism in the name of religion in Bangladesh (Mostofa, 2019) which facilitate the terrorist group like AQIS and IS to establish radical narratives (Parvez, 2019). Mostofa and Boyele (2019) find that most of the terrorists are from secular institutions and have mostly a middleclass background. This is also evident from the study of Riaz (2016), and Riaz and Parvez (2018). These literature are mainly based on secondary literature except a very few. Most of these authors mainly used their own arguments throughout their studies and thus these lack comprehensiveness. In this situation, a comprehensive research is required to understand the causes of religious extremism in connection to Islam from the Bangladesh perspectives.

\section{Findings and Analysis of the Data}

Based on field work, here the present writer is submitting I am presenting some key findings behind the causes of terrorism in the name of religion in Bangladesh. This presentation is based on the semi-structured interviews only. Secondary data has not been used in this section. Firstly, the causes of terrorism in the name of religion inBangladesh has been analyzed and secondly, it has been clarified whether terrorism has any real connection whatsoever to Islam. 


\subsection{Education System and Lack of Chances to Know Other Religions}

Bangladesh has many kinds of education system in different phases including general education like schools, Aliya Madrasa education, Qaomi Madrasa education, Ibtedayi and others. In this entire process, students are obliged to study their own religion. For instance, in schools, students are taught only their respective religions. As Islam is the religion of the majority in Bangladesh, 90 percent students are taught only Islam in school. On the other hand, a large number of students in madrasas study Islam rigorously. In the entire process, there is hardly any chance to get to know each other's religions. For instance, a Hindu student hardly gets any chance to know Islam or Buddhism. This lack of chance of knowing other religions in turn is a reason behind terrorism in the name of religion in Islam. One of the respondents remarked that if a student does not know other religions, there is hardly any chance that there grows a sense of harmony and respect in him or her towards other religions. Respondents pointed out that it is required to lessen the prevalent gaps regarding knowing other religions. One of the respondents says: "It is quite unfortunate that our education system is neither fully secular nor fully inclusive. Our education system, through religion, systematically produce intolerance towards people belonging to other religions. This is why, opportunity to know other religions should be institutionalized". Previously, it was customary to claim that Madrasas are a breeding ground of religious extremism, but this stereotyped concept has changed. Students from secular educational institutions or even English medium school background students are joining the terrorist groups in Bangladesh.

\subsection{Financial Limitations}

Bangladesh has a poverty rate of just above 20 percent at this moment whereas Bangladesh has been depicted as a development model for the least developed countries. A successful journey of Bangladesh significantly reduced poverty line from $40 \%$ to $20 \%$ in the last decade. But still, poverty is a curse in Bangladesh which is a major cause for many social crises and terrorism in the name of religion has an origin in it. According to the respondents, poverty is a driving force of terrorism in the name of religion in Bangladesh. One of the respondents says: "Terrorism has a direct link to relative deprivation theory. When people are deprived and lead a poor life, the chances of getting involved in terrorism or religious extremism is really high". Terrorist groups most often target youth from marginalized section for recruitment. They try to attract them with money and rigorous narratives which one often misleading. Even, it is comparatively easier to bring these people in the path of terrorism because of socio-economic condition of Bangladesh, argued by one of the respondents.

\subsection{Unemployment}

It is true that a complex socio-cultural and socio-economic environment is helpful for the rise of terrorism. It cannot be denied that Bangladesh has been going through such a crisis since her independence. This instability and environment created opportunity for the perpetrators in different times to increase the number of terrorists in a group. Bangladesh has been critically suffering from unemployment problem in the face of the overwhelmingly growing number of graduates which is produced every year in Bangladesh. The percentage of unemployment among the educated youth is above 40. Most of 
the respondents have remarked that unemployment is a key factor behind the rise of terrorism in the name of religion. When the terrorists or perpetrators try to recruit an unemployed person, they try to capitalize their helplessness. For instance, a respondent said: "If a potential recruit is seen having suffered with poverty or lack of job, they allure that potential with money and a future. For a better future or even getting frustrated with unemployment, they try to explore a new adventure".

\subsection{Social Media and Internet}

Social media such as Facebook, twitter, Instagram and so on have twofold effects. In one hand, it is a good way to connect people around the world as well as a new era of citizen journalism as well. But on the other hand, it is the master of fake news and propaganda. These fake news and propaganda have tremendous effects on the society as these have been creating confusion and chaos in many countries only based on rumors. In this social media age, the terrorists are not lagging behind using social media to recruit new members in their groups. According to most of the respondents, social media have been acting as helping hand of the terrorists. They are circulating their misguided messages through different social media, Facebook in particular. According to one of the respondents: "Extremists circulate their teachings through internet which is a major way of getting access to extremist information. These gateways such as YouTube, Viber, WhatsApp, Facebook and Twitter have significantly helped the terrorist organizations to attract more young people. For instance, many youths were radicalized in Europe in the last decade who joined IS or Al Qaida in different times."

\subsection{Global Rise of Religious Militancy and Identity Crisis}

Religious terrorism has a connection to the global rise of religious militancy which is largely backed by identity crisis of the Muslims in the middle east, in particular. Over the last couple of decades, militancy has become a global crisis fueling in many parts of the world. International terrorist organizations such as Islamic States or Al Qaida which spread in many parts of the world and recruited a significant number of youth showed that there are some reasons for their expansion. They have small operational units in many countries or regions; such as AQIS, sister concern of Al-Qaida to continue their terrorist acts in the Indian subcontinent. International terrorist groups try to induce an idea of deprivation of identity. One of the respondents says: IS or Al Qaida use the lack of the Muslim solidarity as their safeguard, use identity crisis as tool to recruit new targets." All the respondents have told that when there is a rise of religious militancy or terrorism, the wave of that current certainly affects Bangladesh as well.

\subsection{Political Unrest}

Bangladesh has been struggling with political instability since 1975 after the assassination of the father of the nation, Bangabandhu Sheikh Mujibur Rahman. Most of the respondents have argued that political instability makes an advantageous situation for the spreading and genesis of religious terrorism. A respondent says: "Bangladesh has been suffering from religion-based terrorism largely due to the lack of political stability. Terrorists try to induce terror and fear when there are insurgencies. For instance, capitalizing the political instability, extremists induced violent activities in 2014 and 2015 in the country." Political unrest stirred the 
spread of terrorism in the name of religion for two reasons. Firstly, sometimes political parties have a link with the terrorist organizations which facilitate the terrorists, says one of the respondents. Secondly, when there are political insurgencies, perpetrators become more successful in convincing the people that the present political structure cannot bring peace. Thus, political unrest acts as one of the key reasons behind the expansion of religion based terrorism in Bangladesh.

\subsection{Psychological Issues}

Terrorism does not occur only due to social crisis or poverty or education system. All the respondents have argued that it is close to impossible for any psychosocially sound person to kill people and to bomb in mosques. Only those who are psychologically weak or frustrated, become terrorists. Though this statement is just a mere generalization, it cannot be easily denied that frustration is a key reason to induce a terrorist. Broken love affairs or broken family crisis can induce frustration in an individual, leading to other means to get rid of this problem. One of the respondents says: "When people are psychologically weak and suffer from family crisis or relationship, the chances of being terrorist is high."

\section{Islam and Terrorism Debate}

There is a constant debate whether Islam has direct relationship to terrorism. But in this study, it has been found that hardly any theological relationship exists between these two opposite entities; religion and terrorism. The factors behind the rise of religion-based terrorism are more primarily mundane and dependent on social factors. All the respondents are agreed that Islam is a religion of peace and it has hardly any connection to terrorism. One important term must be analyzed in contextual framework and that is 'jihad', says one of the respondents. According to them, when jihad as a term is wrongly used and explained, there is a significant chance of taking a violent path by an individual who by and large get motivations from the perpetrators. A respondents says: "There are two kinds of jihad of which the greater jihad that is to fight against inner evil spirit of ourself and the lesser one is to fight on enemy or social evils'.

\section{Conclusion and Recommendations}

Terrorism in the name of religion in general and of Islam in particular has become a global concern as the perpetrators have been repeatedly misinterpreting Islam for their own interests. Terrorists are also using the pious minds of the Muslims to capitalize on their own goals and desires. From the above arguments, it is possible to prove that terrorism in the name of religion is not a result of any particular cause. Every individual might have different reasons for being a terrorist. But apart from subtle individual causes, a few general causes have been identified and explained from practical perspectives including poverty, education, social and political unrest, global rise of Islamic militancy, and different psychological issues. In one hand, these causes are well integrated as all these causes are socially constructed and drive people to come closer to extremist teachings; and on the other hand, not all causes drive a particular individual to be a militant, one cause is enough to make a potential target to be an extremist. Moreover, it has been argued that terrorism has not any connection to Islam. In Bangladesh, some organized groups are capitalizing the Islamic sentiment of people for their personal and group gains. The idea of ji'had has been very much misinterpreted in 
Bangladesh as in the rest of the world. Extremists try to equate this idea with terrorism. As a result, the habitual critiques of Islam easily get chance to criticize Islam as a religion of the jihadists. It is high time, the government should come forward to take preventive measures to countering the religious terrorism in Bangladesh. It is always wise to take preventive measures than taking post-terror measures. Based on this study, a few recommendations for the policy makers have been suggested below.

Firstly, the socio-economic condition of the underprivileged youth should be improved through some inclusive socioeconomic steps. For instance, the government and the rich private organizations can increase the number employment in the of job sectors and ensure loan for the young potential entrepreneurs for creating self-employment.

Secondly, studying of world religions including Islam, Hinduism, Christianity, Buddhism, Judaism, Sikhism and others should be made compulsory from Secondary education both in schools and Madrasas so that an attitude of respecting others grows at an early age. This will help a lot in growing up the upcoming generations.

Thirdly, an awareness campaign against terrorism and extremism should be carried out throughout the country on a regular basis so that people become aware of the deadly consequences of terrorism in the name of religion.

Fourthly, vocational education instead of general education should be made more attractive. In the present situation, vocational education is not popular in Bangladesh. Students receiving vocational education should be ensured with job security after completion of their study. In addition, their degrees should be practically made equivalent to general degrees.

Finally, the imams of the mosques specially those who give Friday sermons should be trained on interfaith harmony and Islam's peaceful attitude towards other religions. If they repeatedly put emphasis on how terrorism in the name of Islam is contrary to the ideal ofIslam, people will be more aware of it and this will significantly lessen the chances of joining extremist groups by the youths.

\section{Bibliography}

Anisuzzaman. 2015. Communalism And Secularism. Dhaka: BPL.

Bashar, Iftekhar. 2015. ISIS, AQIS and the Revival of Islamist Militancy in Bangladesh Counter Terrorist Trends and Analyses. 7(6). pp. 18-23.

Barakat, A, Rawshan, Taheruddin And Badiuzzaman. 2013. Political Economy Of Madrassa Education In Bangladesh: Genesis, Growth And Impact. Strategic Analysis. 37(4).

Bangladesh Institute of Peace and Security Studies. 2017. Local Drivers and Dynamics of Youth Radicalisation in Bangladesh. Dhaka: BIPSS.

Barakat, Abul. 2018. Fundamentalism In Bangladesh: External And Internal Dimensions Of The Political Economy Of Militancy. Dhaka: Muktabuddhi Publications.

Barkat, Abul. 2018. "Political Economy of Fundamentalism and Fundamentalist Extremism in Bangladesh". Dhaka: Bangladesh Economic Association.

BEI. 2015. The role of education in countering radicalization in Bangladesh. Dhaka: Bangladesh Enterprise Institute.

Calvert, John. 2010. Sayyid Qutb and the Origins of Radical Islam, London: Hurst. 
Bar, Shmuel. 2004."The Religious Sources of Islamic Terrorism," Policy Review. 125 (June/July): 27-37.

Hafez, M., \& Mullins, C. 2015. The radicalization puzzle: A theoretical synthesis of empirical approaches to homegrown extremism. Studies in Conflict \& Terrorism, 38(11), 958-975.

Hardy, K.2018. Comparing theories of radicalization with countering violent extremism policy. Journal for Deradicalization. No 15.

Islam, Md Nazrul \& Islam, Md Saidul.2018. Politics and Islamic Revivalism in Bangladesh: The Role of the State and NonState/Non-Political Actors, Politics, Religion \& Ideology, 19:3, pp. 326-353, DOI: 10.1080/21567689.2018.1493382.

Islam, M.D. 2019. De-Radicalisation of Terrorists: Theoretical Analysis and Case Studies. Counter Terrorist Trends and Analyses, vol. 11, no. 5.

Islam, M.D. and Siddika, A. 2020. Exploring the causes of extremism in Bangladesh.The Journal of Dhaka University Studies.72(1-2).

Islam, MD. 2020. Understanding secularization as indicating the process of the separation of the political and religious. The Arts faculty Journal. 10(14-15), pp. 127-139.

Islam , MD. And Huda, F. 2016. Religion and Politics: Bangladesh Perspectives. International Journal of Management and Humanities (IJMH). Volume-2 Issue-4.

Islam, M.D. 2019. Religious Freedom for the religious minorities in Bangladesh: A critical analysis of the insertion of state religion in the constitution. The Arts faculty Lecture 2019. OSF Preprint.

Khan, Shahab Enam. 2017. Bangladesh: The Changing Dynamics of Violent Extremism and the Response of the State. Small Wars \& Insurgencies, 28(1). pp. 191-217, DOI: 10.1080/09592318. 2016.1266127.
Khan, Moinul. 2011. Islamist militancy in Bangladesh: why it failed to take root, Journal of Policing, Intelligence and Counter Terrorism, 6:1, 51-64, DOI: 10.1080/18335330.2011.553181.

Mostofa, Shafi and Doyle, N.J. 2019. Profiles of Islamist Militants in Bangladesh.Perspectives on Terrorism.13(5).

Mostofa, Shafi. 2020. Key drivers of female radicalizations in Bangladesh. Counter terrorist and trend analysis. 12(4).

Rahman, M. 2017.Islamist radicalization in Bangladesh. Dhaka: Srabon Publications.

Riaz, Ali \& Parvez, S. 2018. Bangladeshi Militants: What Do We Know?, Terrorism and Political Violence, 30:6, 944961, DOI: $10.1080 / 09546553.2018 .1481312$.

Riaz, Ali. 2015. How did We Arrive Here, Prothoma Publications, Dhaka.

Riaz, Ali. 2018. Lived Islam and Islamism in Bangladesh, Prothoma Publications, Dhaka.

Riaz, Ali. 2012, Inconvenient Truths about Bangladesh Politics, Prothoma Publications, Dhaka.

Randy Borum, 2011."Radicalization into Violent Extremism I: A Review of Social Science Theories," Journal of Strategic Security.Vol-4, No-4.

Sageman, M. 2004. Understanding terror networks. Philadelphia: University of Pennsylvania Press.

S.A. Khan. 2009. in I. Ahmed (ed.), Terrorism in the 21st Century: Perspectives from Bangladesh. The University Press Limited.

Fund: This research was funded by the University of Dhaka from the University Grants Commission of Bangladesh 2018. A modified version has been presented for publication. 